\title{
Higher education and economic innovation, a comparison of European countries
}

\author{
Cecile Hoareau $^{1 *}$, Jo Ritzen ${ }^{1}$ and Gabriele Marconi ${ }^{2}$
}

\author{
* Correspondence: c.hoareau@ \\ maastrichtuniversity.nl \\ ${ }^{1}$ UNU-MERITMaastricht University \\ Keizer Karelplein 19,6211 TC \\ Maastricht, Netherlands \\ Full list of author information is \\ available at the end of the article
}

\begin{abstract}
This paper compares higher education policies across thirty two European countries, using the contribution to economic innovation as a benchmark for the comparison. We suggest that an increase in university autonomy and public funding, that we qualify as 'empowerment', positively affects the research and education performance of universities, and more importantly the innovation potential of countries. We subsequently formulate policy related recommendations for Europe.
\end{abstract}

\section{Introduction}

56 Euros of GDP was generated per hour worked in Norway in 2010 but only 14 Euros per hour in Bulgaria according to the statistics of the European Commission (2011a, b). What can explain these differences across Europe? Why and to which extent have some European countries become more innovative than others? And what is the role of higher education, and particularly the higher education policies, in a continent where higher education is mainly publicly funded, in the generation of innovation?

The European Union aims at becoming an Innovation Union with its Europe2020 strategy, even though the EU stagnates on one of the innovation metrics vis-à-vis the rest of the world: China quadrupled the number of patent applications submitted to the International Patents Office to 415,829 between 2005 and 2011, while this number remained more or less the same in the EU over this period with around 100,000 applications (World Bank 2013).

The term innovation has several meanings. We define an innovative economy as one driven by the implementation of new or significantly improved products, processes, new marketing or organizational methods in business practices, workplace organization or external relations (adapted from European Commission and OECD 2005: 16). We proxy in this paper "innovation" by on the one hand "productivity per hour worked" as an outcome and on the other employment in knowledge intensive activities as an input. Measures such as patents and intellectual property rights are often used to proxy innovation. However, patents are a short-term output. Productivity is the outcome that patents seek to achieve. Organizational innovations can also increase a firm's performance by reducing administrative and transaction costs, and hence increase productivity (European Commission and OECD 2005: 51). We concentrate particularly on labor productivity (value added per hour worked), given that labor productivity is more likely to be influenced by education than capital productivity. 
This relationship between education and labor productivity is complex, especially when considering the influence of technology and physical capital. Technological progress itself does not come from heaven, but is the result of new vintages of human or physical capital with higher productivity levels (Solow 1956; Swan 1956; Grossman and Helpman 1991; Barro and Sala-i-Martin 1995 and Aghion and Howitt 1998). At the same time, the changes in the productivity levels of new vintages of physical capital could be the result of the involvement of knowledge workers in the production process. This is the reason why we also use employment in knowledge intensive activities as a proxy for the innovation in a country because we assume that innovative economies have a broader knowledge intensive industry than other economies.

The ultimate objective of economic innovation is to achieve economic growth. Yet, we have chosen to steer away from economic growth data given the erratic trends in growth over the peculiar period of investigation (2008-2012) ${ }^{1}$.

We concentrate on higher education because that is the level of education which provides the advanced skills necessary for a high innovation environment. Higher education serves a variety of purposes, but the contribution of higher education through the productivity of workers is an important one. More specifically, we concentrate on higher education policies and their impact on the performance of higher education across European states, so as to better understand how higher education public policy is related to economic growth.

We surmise that "empowerment", a notion which points to the appropriate regulatory environment characterized by university autonomy and the appropriate material conditions, is related to productivity increase of the labor force, through the skills of a mobile pool of graduates and research performance.

We compare higher education policies across a broad set of 32 European states, using proxy indicators for policy, for the performance of universities and for innovation, all registered on the country level, in a simplified model in which performance is related to policy (with a time-lag) and innovation/productivity follows performance. "European" is here used to extend beyond the EU. Also Turkey is part of our sample of 32 states. With our approach we also address a methodological flaws related of the ranking for higher education, which attribute subjective weights to various indicators in order to derive a total score. This paper proposes a way to provide non-arbitrary weights based on a statistical analysis with a crude model in order to derive a total score. The paper complements an earlier publication (Hoareau et al. 2013). It provides a more in-depth overview of key indicators and of the relationship between these education and economic indicators.

The paper is structured as follows. Section 1 provides a brief overview of the relevant literature on human capital accumulation, economic innovation and education. Section 2 explains the indicators we have used for innovation, higher education policy (autonomy and funding) and the performance of higher education institutions. Section 3 presents a descriptive overview of these indicators and their relationships using simple regression analyses. Section 4 presents the non-arbitrary comparative method which relies on factor analysis. Section 5 presents some recommendations.

\section{Literature review}

The accumulation of knowledge through education can increase labor productivity, innovation and growth. This occurs through the change in the quality of new vintages of 
human capital (Kim 1998; Van Zon and Antonietti 2004; Hanushek and Woessman 2012), leading to "labor saving" of low skilled workers, as a result of the automation of routine jobs. In the past four decades the supply of skilled workers increased rapidly, but demand outpaced the supply, leading to an increase in the wage premiums for well trained workers. This is the race between technology and education, a term coined by Jan Tinbergen. The race has been lost by education, because it was not only racing to keep up, but at the same time contributed to technology (Acemoglu 2002).

The relationship between skills-acquisition - education - and technological change is likely to be non-linear. Van Zon and Antonietti (2004) showed that an increase in the level of formal education can lead to a reduction in the rate of growth. They explain this phenomenon as the creative destruction process: increasing innovation increases the need for re-training spells, which leads to 'technology adoption costs' due to output foregone during the re-training periods. Ritzen (1976) also explained this phenomenon through the investment costs needed for formal education, which reduce the room for private consumption.

Human capital does not affect innovation uniformly. Vandenbussche et al. (2006) argued that a more educated workforce does not only facilitate the creation of new technologies, but also increases the country's capacity to adopt technologies already developed elsewhere. This facilitates cross country convergence and the process of "catching up" (Barro 1991, Barro and Lee 1993, Baumol 1986; Benhabib and Spiegel 2005; Kneller and Stevens 2006). Goldin and Katz (2008) find that advances in education attainments (measured by degrees achieved) account for $15 \%$ of the $2.23 \%$ per year gain in real GDP per capita from 1915 to 2005. This effect could be higher if the potential impact of (higher) education and public research on the speed of "unskilled labor saving" or "human capital enhancing" technological progress had been taken into account. They furthermore note that technical change is not only skill-based.: innovations in the early twentieth century were also passed on to less skill-intensive sectors, like electricity.

The positive impact of higher education increases as countries come closer to the technology frontier (Vandenbussche et al. (2006), as shown empirically by Aghion et al. (2009a,b) for developed countries, and Ang et al. (2011) for developing countries). Technological change increases the demand for expert thinking and complex communication ("non-routine work"), acquired through higher education (Levy and Murnane 2005). The contribution of (higher) education occurs through the provision of quality education rather than merely a quantitative expansion, as Hanushek and Woessman (2012) have shown using internationally comparable assessments; and as Asteriou and Agiomirgianakis (2001) similarly demonstrated for Greece.

Before 2000 research on human capital and economic growth concentrated on the impact of the number of years of education in the working population on GDP. It turned out that such a relation could not be established with a substantial significance (Pritchett 2001). A major turn-about came with Barro (2001) who underlined the role of education for longterm economic growth using both years of education as well as a measure of educational quality (the internationally comparable assessments of PISA). Also Kimko and Hanushek (2000) find that scores on international examinations (as indicators of the quality of schooling capital) mattered more than years of attainment for subsequent economic growth.

Public policies play an important role in enhancing the outputs and quality of higher education. This study concentrates on public financial investment and on autonomy, two 
components of what we refer to as university 'empowerment' (Hoareau et al. 2013). European-wide the notion of university autonomy has been heavily debated in public policy, with various reforms aiming at increasing the autonomy of universities from the Central Government or State Governments, for example by giving universities the ability to manage themselves financially. Universities in Europe are largely publicly funded (75\%) amidst efforts to diversify funding. Yet funding is also highly controversial in the public policy debate.

The literature provides evidence on the correlation between these two policy elements (funding and autonomy) and university performance. Acemoglu et al. (2006) and Aghion et al. (2007) find that investments in research-related education are likely to pay off for areas which specialize in innovation and are close to the world technological frontier. Aghion et al. (2009a, b), along the pathways of Volkwein (1986) and Volkwein and Malik (1997), investigated the impact of other public policies, like the governance mechanisms of universities on research output using the number of patents and the position of the university in international research rankings as university performance indicators. They found that university autonomy and competition were positively correlated with university outputs across the US and Europe. They also found a positive relationship between funding shocks and patent production when public universities are more autonomous and more competitive.

\section{Indicators}

Our analysis of the impact of innovation policies on economic innovation relies on a set of eighteen statistical indicators. These indicators are described below ${ }^{2}$. In some cases the available data did not cover all countries. We calculated missing values using regression analysis (for details: see the technical report, Hoareau, Ritzen and Marconi, 2012). In other words, we used proxies from other sources in order to predict missing values. For example, regarding public expenditure per student as a percentage of GDP per capita, we have used similar World Bank indicators for 2008, as well as 2006 when 2008 data was unavailable (as was the case only for Turkey), to predict the data points which were missing in the OECD database.

\subsection{Economic innovation}

Economic innovation is measured by labor productivity and the percentage of employees in Knowledge Intensive Activities (KIAs). More innovative societies are likely to have both a higher labor productivity as well as a higher percentage of employees in Knowledge Intensive Activities $^{3}$. Labor productivity - GDP per capita per hour worked - strongly relates to employment in Knowledge Intensive Activities. Moreover, North-Western European countries, like Norway, Luxembourg, Sweden, the UK, the Netherlands, and Iceland, appear to be the most innovative across Europe in terms of KIAs.

\subsection{Higher education policies}

\section{- Autonomy}

The indicators of higher education policies we have used to look at the relationship with innovation are autonomy and public funding. Autonomy is understood very differently across European countries because of differences in culture and history. For example, in 
Germany and France, autonomy is traditionally connected with the specific notion of 'academic freedom,' namely that professors of the universities (the Senate) -once they are appointed- choose their own leadership and decide themselves on the design of the degree programs and the research subjects and content, within location, staffing and funding arrangements decided by the Government. In the UK and the Netherlands, in contrast, autonomy is the ability of institutions to function independently from the Government (in terms of raising and managing their own funds etc. and in terms of the freedom to choose the subject and content of education and research), while the concept of academic freedom is no longer a matter of the interpretation of the Senate, but for the appointed leadership of the university.

There are also differences between countries in terms of the autonomy to attract students. In some countries the number of places that the Government will finance in a university is decided by the Government. In other countries a university can enroll (with Government funding) all students who apply and are admitted. Studies which are subject to a numerous fixus imposed by Government are an exception.

To capture different notions of autonomy, we use three concepts, namely organizational, policy and financial autonomy.

Organizational autonomy measures the extent to which a university is allowed to decide on its own organizational structures, its own internal authority-, responsibility- and accountability structures, as well as its institutional leadership. Organizational autonomy includes the notion of a supervisory board for the university which appoints the top leadership of the university (the president, board or rector), where the top leadership appoint the deans and the professors.

Policy autonomy includes the ability of universities to create academic communities through the selection of staff and students and to determine their teaching and research programs (it includes "staffing" and "academic autonomy").

Financial autonomy is related to a university's ability to attract income from additional funding sources, to be able to decide on the internal allocation of funds, to build reserves and to borrow funds on the capital market. University systems in which Governments allocate funds by line items, where unused funding has to be returned at the end of the year, or where universities cannot borrow money or develop alternative funding sources are considered not to be financially autonomous.

A shift in the degree of autonomy does not automatically lead to a reduction in Government control. For example, the retreat of a priori command and control system in some continental countries (such as having the Government laying down the national-wide curricula) towards more posteriori quality control mechanisms (based on an a posteriori evaluation of programs), may imply a displacement of the relative role of the Government rather than a retreat.

Autonomy may also be experienced differently at different levels within the university. Musselin (2004) shows for French institutions that more university autonomy from the Government may well imply that the university leadership decides on a strategy which limits the freedom of academics more than in the situation of more Government control. Van Vught and Neave (1991) give a description of the changing role of the relationship between universities and the Government as a move away from state control to state supervision.

The Center for Higher Education Policy Studies CHEPS, INCHER and NIFU-STEPS (2008) have assessed these dimensions of autonomy through a questionnaire sent to and 
answered by national experts and through interviews with relevant stakeholders. They coded the extent to which autonomy has been achieved in organizational, policy and financial autonomy on an ordinal scale from 1 (low) to 5 (high) (for organizational autonomy) and 1 (low) to 3 (high) for policy and financial autonomy. The scores only reflect a comparative picture at the national level. They ignore possible differences on the regional, federal or institutional level within a country. They indicators also do not capture differences that may exist in levels of autonomy across degree courses, for example in the selectivity of undergraduate versus postgraduate degrees.

\section{- Funding}

Our first indicator for funding is the effort that countries make, namely annual expenditure per student by institution for all services related to higher education relative to GDP per capita in $2008^{4}$ (OECD 2011: 221). The services include core services such as teachers; school buildings, teaching materials and school administration. They also include ancillary services. Measuring the full-cost of higher education institutions is a challenge in several European countries, because of the different funding streams related to a university for research or for education (Estermann and Kanep 2008).

Research expenditures of universities include expenditures financed through private and public sponsors and separate grants. This is an average measure for the whole country. Underneath are substantial differences between (types of) higher education institutions, for example, in France between universities and selective professional schools "grandes écoles", or in the UK between the prestigious University of Oxford and institutions which acquired the status of university more recently.

A second funding indicator is public subsidies to households and private entities as a percentage of total public expenditure on higher education in 2008 (data from Eurostat). One might hypothesize that countries which are able to generate the broadest participation of the pool of talent would also be the most able in increasing human capital- led -innovation. A way to improve access is to invest in financial aid schemes, such as grants, scholarships and loans. Extra child allowances and extra tax deductions are also used in Europe as instruments to support parents with children in university. Student grants and more recently loan schemes (in some cases the latter have been replacing the former) have been implemented in all European countries.

We realize the imperfection of our present measure as we do not control for the private costs in the country. For example, if $100 \%$ of the direct costs of education were private, then public subsidies to higher education would be $100 \%$ (there would be no other expenditures). At the same time our indicator (the relation to tuition costs) would not be a problem if private costs were more or less the same in Europe. However, countries like the UK, Portugal and the Netherlands have (considerable) higher tuition fees than the rest of the countries.

One should bear in mind that other measures, like the availability of state-funded places might also affect equality of opportunity (besides financial aid), to promote access. For example, the reduction of the number of state-funded places in Hungary between 2000 and 2012 from roughly 60,000 to 35,000 (plus 15,000 places with 50\% funding) could well have had a (substantial) impact on the composition of the student force by parental background with the likelihood that inequity will be increasing ${ }^{5}$.

Subsidies in the form of grants loans and scholarships show a large variation in Europe, ranking from around 50.9\% of public expenditure for tertiary education in Cyprus to merely 
$1.5 \%$ in Poland ${ }^{6}$. The UK has by far the largest public loan scheme, to compensate for the highest tuition fees in Europe. The UK ranks high in terms of the availability of facilities, but the trend is towards (slightly) less availability of loans and grants. The same holds true for the Netherlands.

There is considerable political debate (Johnstone and Marcucci 2010) on the impact of loans on student choice behavior and on the distribution of the risk of non-completion or inability to pay back between the lender and the Government. Some scholars argue in favor of grants over loans for students from low income backgrounds with the rationale that debt aversion is correlated with social background, even though it appears that the introduction of student loan schemes did not affect negatively the number of applications from students from a varied backgrounds if one controls for their grade after high school (Babb et al. 2004: 17). However, that does not yet undercut the argument in favor of more aid to students from poor backgrounds, as they might not have had the same chances to develop their ability.

\section{- University performance}

Public policies in higher education affect economic innovation through the outputs of the higher education system. Traditionally, studies have concentrated on the outputs of higher education in terms of research, as well as in terms of educational output measured by attainment rates. Here we use as indicators for university research, including: a- Scientific publications within the $10 \%$ most cited scientific publications worldwide as a percentage of total scientific publications of a country the percentage of universities in the ARWU proportionally to the population; b- the number of incoming Marie Curie and young European Research council starting grant winners per million inhabitants; c- private-public co-publications per million inhabitants.

The indicators for the education output are: a- the number of enrolled students as a percentage of the population of corresponding age; b- those entering higher education through an alternative route; c- graduation rates (graduates relative to enrollment); c- graduate employment rates of 18-34 year olds three years after graduation; d- the percentage of inward mobile students proportionally to the student population in the host country. All the performance indicators were taken between 2008 and $2011^{7}$.

This mix of indicators allow us to measure different dimensions of the quality and quantity of the higher education performance, namely not only educational attainment and publication outputs, but also the openness of a higher education system (both in terms of education and research), international students and staff as well as for students from non-traditional backgrounds, its connections to the private sector (private-public co-publications), as well as the employability of graduates.

\subsection{The higher education landscape in size}

Figure 1 gives an impressionistic view of the European higher education landscape in terms of student numbers and the size of the population.

Countries have a different participation rate in higher education because they have a different demographic composition. Countries with a young population (like Turkey) will have more students. Other countries like Germany, the UK or France, have had expansionary policies in higher education, for example with the widening participation programme in the UK. 


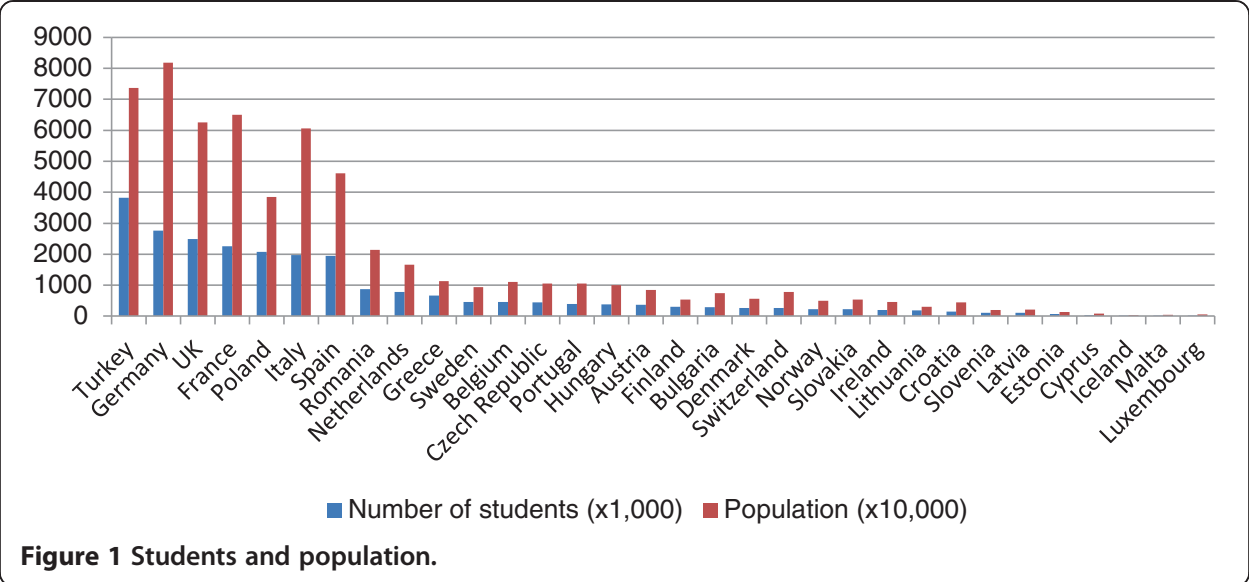

This paper takes these considerations into account by including measures of size, either in terms of enrolment numbers (regarding the education performance), number of inhabitants (for research performance) or some general economic measure (GDP per capita for example).

\section{A comparative overview}

Figure 2 summarizes the data for the thirty two European countries of our sample in the form of comparative graphs by groups of indicators.

Figure 2 shows some systemic differences. For example, higher education systems, of Sweden, the UK, Ireland and Finland, appear to be relatively open regarding the inclusion of students from various backgrounds, i.e. traditional secondary education or alternative routes such as work experience, vocational training or prior learning ${ }^{8}$. But others, like Italy and Poland, do not have a tradition of welcoming students from non-traditional routes.

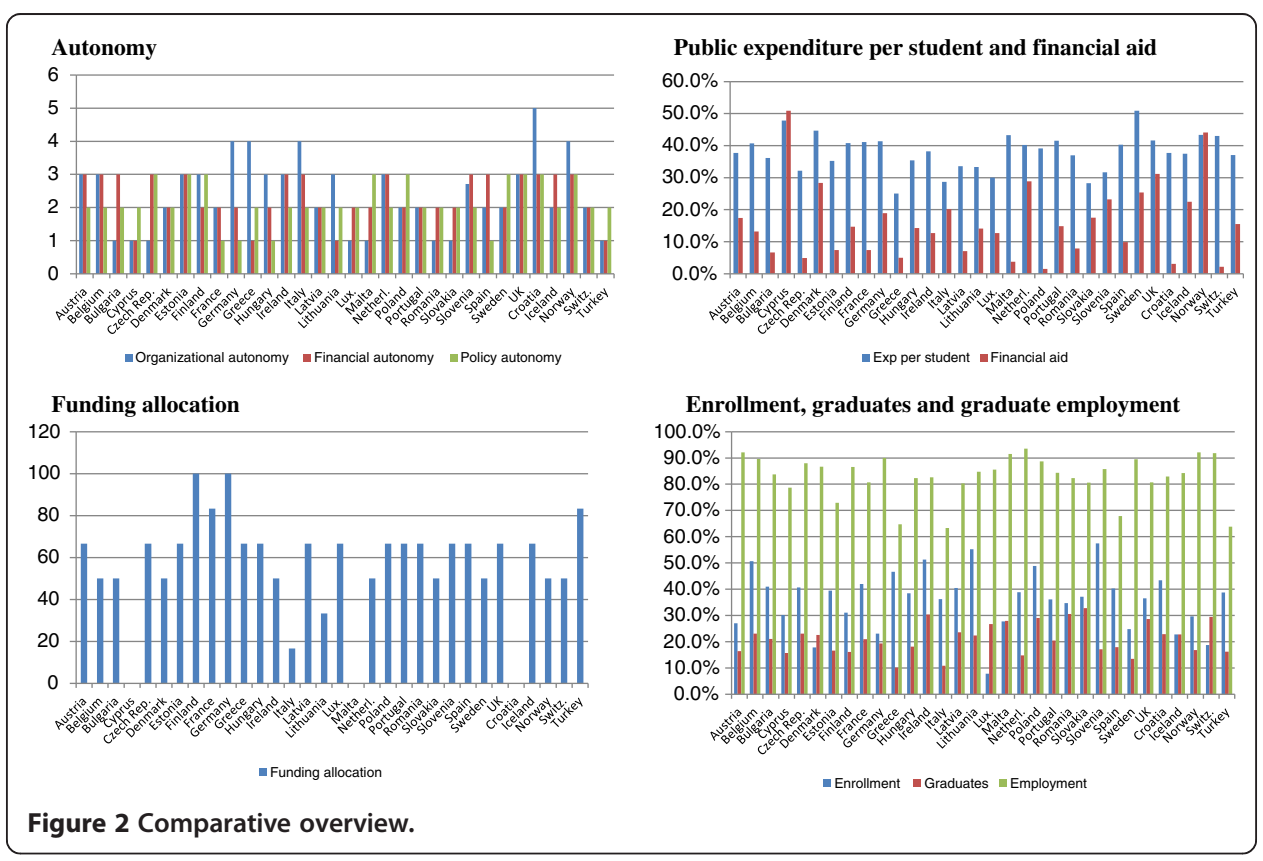




\subsection{A divided Europe: the discrepancy between Northern/Western Europe and Southern/ Eastern Europe}

Figure 2 also shows a certain - not unexpected - discrepancy between Northern/some Western European countries and Southern/Eastern European countries. Public expenditure to tertiary education as a percentage of GDP per capita was twice higher in Sweden (50.9\%)

${ }^{9}$ than in Greece $(25.1 \%)^{10}$ in 2008. Cyprus is a notable exception, with one of the highest percentages of public expenditure in tertiary education of Europe in 2008. The Cypriot Government had invested (comparatively) heavily in higher education over the past two decades to expand higher education. Cypriot universities are relatively recent. Following the creation of three public universities in 1989, 2002 and 2003, a further four private universities have been created. And Cyprus was also part of the group of countries having achieved the target of 40\% of 30-34 year olds with a higher education degree in 2012 (European Commission 2013). However, it is unlikely that Cyprus can maintain these financial outlays for universities, given the difficult, present situation.

Research attractiveness and -productivity are highest in Northern and Western Europe. Switzerland and the Netherlands had the highest number of publications in the most cited scientific journals in 2007. Together with the UK, they were also the most attractive countries for European researchers under the prestigious Marie Curie scheme and recipients of the European Research Council starting grants.

This concentration of research attractiveness and productivity around Northern and Western European countries may have a self-reinforcing effect: highly talented students and researchers 'vote with their feet' by moving toward the most rewarding systems. This effect may have become accentuated by the economic crisis in the aftermath of the financial crisis of 2008. Governments of countries which are less attractive should consider this as a challenge, namely by providing as a priority the means to their higher education systems to be competitive on a European and international scale. The convergence in the quality of higher education and research relates to further convergence in innovation in Europe and ultimately to a continuation of the convergence in GDP per capita. The major challenge for the EU seems to be to bring convergence in the development of higher education and research within Europe, not by delaying the fast runners, but by spurring those lagging behind.

Some education metrics also reveal a certain discrepancy between North/West and Southern Europe, the Netherlands, Sweden, Norway, Switzerland and Germany have some of the largest rates of graduate employment. $93.5 \%$ of graduates were likely to be in employment three years or less after graduation in 2010 in the Netherlands. This relatively high employment rate is likely to be influenced by the active role of the social insurance agencies and municipalities in contracting out work placements to employers for unemployed youth. Moreover, access to unemployment benefits has become more tied up to work experience with six months of work required (OECD and European Commission 2008: 6). Conversely, Greece and Italy have some of the lowest graduate employment figures. As a response, the Greek Government has tied the funding of universities to the employability of the graduates in the law (4009/11).

But the wealthiest countries in Europe do not always have the best performance across all metrics of higher education. Graduation rates in Germany and the Netherlands appear to be lower than the average; the independent learning culture or the fairly generous financial aid schemes having been mentioned as potential explanations. 
Some of the largest countries also have a more constrained autonomy, as is the case for France for example ${ }^{11}$. The UK appears as a notable outlier in this respect, with a strong organizational autonomy. British universities are deciding on their own internal authority, including their own legal entities, their academic structures, or their executive heads and governing bodies.

And the countries with the highest enrollment figures are not necessarily those with the highest graduation rates. Slovenia is the most illustrative example. It has the highest difference between enrollment and graduation rate: $57.5 \%$ of the population aged 20 years is enrolled in a tertiary education degree; but only $17.1 \%$ of enrolled students graduated in Slovenia in 2010. In order to reduce such discrepancy, Slovenian higher education institutions could for example review the way it admits applicants in order to make sure that students are oriented toward the course of studies toward there are best suited. They could also provide more support to student learning in order to improve graduation rates.

\subsection{A preliminary analysis of the effect of higher education policies}

One way to understand whether common policy issues across Europe deserve particular attention is to look at the statistical association policies on performance and economic innovation. Table 1 below presents these effects in the form of the beta coefficients of a series of univariate regression analyses. This approach has a number of limitations. For example, the same regression technique is used across data of various type (categorical or interval). Yet, the regression coefficients summarized in Table 1 provide a preliminary indication of the relationships between indicators.

Table 1 provides various relevant pointers. Knowledge employment and laborproductivity significantly relate to an increase in research performance. But they are significantly associated to only part of the set of education-related indicators (i.e. graduate employment, the inclusion of students from non-traditional backgrounds and the enrolment of students). Also, they significantly relate only to a minority of policy indicators, namely the level of financial aid. One additional euro produced per hour is associated to an increase in $0.4 \%$ of the amount of total education expenditure in student financial aid.

Table 1 also shows that there does not appear to be a relationship between policy indicators (except between expenditure per students and financial aid which are logically related $)^{12}$. The countries with the highest levels of expenditure per student are not necessarily the ones with the largest amount of university autonomy. The reforms to increase university autonomy since the late 1990s in Europe have indeed been coupled with a steady reduction of expenditure per students.

In addition, Table 1 provides some insightful preliminary findings related to policy indicators. It shows expenditure per student is the policy measure which is most often significantly related to other outcomes. Higher public expenditures seem to contribute to making a system more attractive, being associated with a higher likelihood for graduates to find employment and to a better research performance of universities. For example, a one percent increase in expenditure per student relative to GDP per capita is associated to an increase in the percentage of international students by 0.48 in comparison to the total student population. A percentage increase in expenditure per student is also associated with an increase by 0.65 percentage points in the employment rates of graduates three years upon graduation and by 29 percentage points in publications in the 
Table 1 Regression coefficients across indicators

\begin{tabular}{|c|c|c|c|c|c|c|c|c|c|c|}
\hline & & \multicolumn{9}{|c|}{ Dependent variable } \\
\hline & & $\begin{array}{c}\text { Organizational } \\
\text { autonomy }\end{array}$ & $\begin{array}{c}\text { Financial } \\
\text { autonomy }\end{array}$ & $\begin{array}{c}\text { Policy } \\
\text { autonomy }\end{array}$ & $\begin{array}{l}\text { Exp per } \\
\text { student }\end{array}$ & Fin. aid & $\begin{array}{l}\text { Financial } \\
\text { location }\end{array}$ & $\begin{array}{l}\text { Internat. } \\
\text { students }\end{array}$ & Transition & Enrolt \\
\hline \multirow{18}{*}{ Independent variable } & Organizational autonomy & & 1.83 & 0.025 & -0.52 & 0.97 & -0.82 & -0.74 & 0.13 & 2.66 \\
\hline & Financial autonomy & 0.46 & & 0.16 & -0.1 & 0.08 & -0.82 & $\begin{array}{ll}-1.98 \\
\end{array}$ & 1.19 & 1.6 \\
\hline & Policy autonomy & 0.07 & 0.19 & & 1.31 & 0.51 & -10.73 & -0.83 & $3.60^{*}$ & -0.16 \\
\hline & Exp per student & -0.01 & 0.00 & 0.01 & & $0.81^{* *}$ & -0.52 & $0.48^{* * * *}$ & $0.59^{* *}$ & $-0.65^{*}$ \\
\hline & Financial aid & 0.00 & 0.00 & 0.00 & $0.19^{* *}$ & & -0.36 & $0.25^{* * *}$ & 0.16 & -0.23 \\
\hline & Financial location & 0.00 & 0.00 & 0.00 & -0.02 & -0.08 & & -0.06 & 0.03 & -0.02 \\
\hline & Internat. students & -0.23 & -0.02 & 0.00 & $0.42^{* * *}$ & $0.92^{* * *}$ & $\begin{array}{ll}-1.06 \\
\end{array}$ & & 0.30 & -0.47 \\
\hline & Transition & 0 & 0.00 & 0.02 & $0.32^{*}$ & 0.37 & 0.33 & 0.19 & & -0.35 \\
\hline & Enrollment & 0.02 & 0.00 & 0.00 & $-0.17^{*}$ & -0.24 & -0.09 & -0.14 & -0.16 & \\
\hline & Graduates & $-0.07^{*}$ & 0.00 & 0.01 & 0.00 & $-0.63^{*}$ & -0.24 & -0.04 & -0.03 & -0.1 \\
\hline & Employment & 0.00 & 0.01 & 0.01 & $0.31^{* *}$ & 0.15 & -0.05 & 0.03 & 0.14 & -0.34 \\
\hline & Top500 Uni. & $1.25^{* *}$ & 0.54 & 0.23 & $7.93^{* * *}$ & 10.61 & 9.55 & 3.27 & $10.24^{* * *}$ & -6.32 \\
\hline & Top publications & 0.07 & 0.02 & -0.01 & $0.67^{* *}$ & $1.28^{* *}$ & 1.12 & $0.59^{* *}$ & $0.86^{* *}$ & $-1.07^{* *}$ \\
\hline & Marie Curie fellos & 0.07 & 0.06 & 0.01 & $1.17^{* * *}$ & $1.47^{*}$ & -0.37 & $1.03^{* *}$ & $1.11^{* *}$ & -1.05 \\
\hline & Public-private co-publications & 0.003 & 0.00 & 0.00 & $0.04^{* *}$ & $0.06^{*}$ & 0.06 & 0.01 & $0.04^{*}$ & $-0.10^{* * *}$ \\
\hline & ERC wins & 0.36 & 0.22 & 0.04 & $2.83^{* *}$ & 3.00 & 4.33 & 1.92 & $2.93^{*}$ & -2.35 \\
\hline & Knowledge employment & 0.01 & 0.01 & 0.00 & 0.18 & 0.40 & -0.03 & 0.21 & $0.51^{* * *}$ & $-0.73^{* * *}$ \\
\hline & Labor productivity & 0.02 & 0.01 & 0.00 & 0.12 & $0.40^{* *}$ & 0.25 & 0.09 & $0.20^{*}$ & $-0.46^{* * *}$ \\
\hline
\end{tabular}


Table 1 Regression coefficients across indicators (Continued)

\begin{tabular}{|c|c|c|c|c|c|c|c|c|c|}
\hline & \multicolumn{9}{|c|}{ Dependent variable } \\
\hline & Grads & Employt & Top500 Univers. & Top pubs & Marie Curie fellos & co-pubs & ERC wins & Knowl emplt & Labor prod. \\
\hline \multirow{18}{*}{ Independent variable } & $-2.20^{* *}$ & -0.31 & $0.13^{* *}$ & 0.93 & 0.38 & 6.95 & 0.23 & 0.7 & 2.33 \\
\hline & 0.41 & 2.58 & 0.14 & 0.86 & 0.84 & 16.64 & 0.35 & 1.95 & 4.11 \\
\hline & 1.02 & 3.07 & 0.07 & -0.67 & 0.26 & 9.45 & 0.09 & 0.19 & -1.65 \\
\hline & 0.00 & $0.65^{* * *}$ & $0.03^{* * *}$ & $0.29^{* *}$ & $0.22^{* * *}$ & $3.89^{* *}$ & $0.06^{* *}$ & 0.31 & 0.52 \\
\hline & $-0.16^{*}$ & 0.07 & $0.00^{*}$ & $0.13^{* *}$ & $0.06^{*}$ & $1.32^{*}$ & 0.01 & 0.16 & $0.40^{* *}$ \\
\hline & -0.01 & -0.06 & 0.00 & 0.02 & -0.03 & 0.29 & 0.00 & 0.00 & 0.05 \\
\hline & -0.03 & 0.05 & 0.01 & $0.22^{* *}$ & $0.16^{* *}$ & 1.33 & 0.03 & 0.32 & 0.32 \\
\hline & -0.02 & 0.17 & $0.02^{* *}$ & $0.21^{* *}$ & $0.11^{* *}$ & 2.07 & $0.03^{*}$ & $0.49^{* *}$ & $0.48^{*}$ \\
\hline & -0.02 & -0.18 & 0 & $-0.12^{* *}$ & -0.05 & $-2.27^{* * *}$ & -0.01 & $-0.33^{* * *}$ & $-0.49^{* * *}$ \\
\hline & & $0.48^{* *}$ & -0.01 & -0.15 & 0.03 & -0.34 & -0.01 & 0.12 & -0.21 \\
\hline & $0.25^{* *}$ & & $0.01^{* * *}$ & 0.1 & $0.11^{* *}$ & $2.76^{* *}$ & $0.03^{* *}$ & $0.36^{* *}$ & 0.41 \\
\hline & -3.93 & $9.90^{* *}$ & & $8.33^{* * * *}$ & $5.43^{* * * *}$ & $98.97^{* * * *}$ & $2.10^{* * * *}$ & $9.25^{* *}$ & $19.62^{* * * *}$ \\
\hline & -0.38 & 0.49 & $0.07^{* * * *}$ & & $0.53^{* * * *}$ & $9.67^{* * * *}$ & $0.19^{* * * *}$ & $1.22^{* * * *}$ & $2.29^{* * * *}$ \\
\hline & 0.19 & $1.30^{* *}$ & $0.11^{* * * *}$ & $1.22^{* * * *}$ & & $13.03^{* * * *}$ & $0.31^{* * * *}$ & $1.52^{* * *}$ & $2.49^{* * *}$ \\
\hline & 0 & $0.07^{* *}$ & 0 & $0.05^{* * * *}$ & $0.02^{* * * *}$ & & $0.01^{* * * *}$ & $0.07^{* * *}$ & $0.11^{* * *}$ \\
\hline & -0.53 & $3.62^{* *}$ & 0.35 & $3.70^{* * * *}$ & $2.55^{* * * *}$ & $40.60^{* * * *}$ & & $4.03^{* * *}$ & $7.47^{* * *}$ \\
\hline & 0.07 & $0.44^{* *}$ & $0.02^{* *}$ & $0.31^{* * * *}$ & $0.16^{* * *}$ & $3.70^{* * *}$ & $0.05^{* * *}$ & & $1.23^{* * * *}$ \\
\hline & -0.05 & 0.2 & $0.01^{* * * *}$ & $0.24^{* * * *}$ & $0.11^{* * *}$ & $2.24^{* * *}$ & $0.04^{* * *}$ & $0.51^{* * * *}$ & \\
\hline
\end{tabular}

${ }^{*} \mathrm{p}<0.1 ; * \mathrm{*} \mathrm{p}<0.05 ;{ }^{* * *} \mathrm{p}<0.01 ;{ }^{* * * *} \mathrm{p}<0.0001$

Note: see Table 2 below for more information regarding the abbreviations. 
top $10 \%$ most cited scientific journals (in comparison to the total number of national publications).

Statistically significant associations are observed among other policy and performance variables as well. For example financial aid positively contributes to attracting international students and researchers (Marie Curie fellows). An additional unit of organizational autonomy is associated with a 13\% higher likelihood to be ranked as a top 500 university (relatively to the population of the country). One additional unit of policy autonomy relates to a 3.60 percentage point increase in the number of students from non-traditional backgrounds.

The systems with the highest levels of public expenditure are not the ones with the highest enrolment levels. Increasing public expenditure by one percentage point of GDP per capita relates to a decrease in enrolment of 0.65 percentage point. This may indicate a potential under-investment in some 'crowded' higher education systems in certain European countries. Moreover, the most research intensive systems also appear to be the ones with lower student enrolment. A one percent increase in enrolment corresponds to a decrease in top publications of 0.12 percentage points. This finding reflects the challenge of matching broad participation in education to 'excellence' in research. Going further, the systems with the broadest enrolment do not appear to be the most innovative ones with the highest levels of labor productivity and knowledge employment. A $1 \%$ higher enrolment rate relates to a decrease of 0.33 Euros of GDP per capita produced per hour and 0.49 percentage points fewer employees in knowledge intensive activities. This finding seems to suggest that quality trumps quantity. In other words, providing students with a relevant teaching and learning experience, and supporting them to graduates, may be more important than simply increasing enrolment numbers. Once confirmed by more methodologically robust analyses, such a finding would have important implications in an era where public expenditures are still often calculated based on the number of students in institutions (although performance-based criteria have gained ground in some European countries).

In methodological terms, running separate regression analyses provided us with a fairly disaggregated picture. But it did not allow us to obtain a set of general findings related to the three main groups of indicators being investigated, namely policy, performance and economic innovation.

\section{The influence of national policies in higher education on innovation in a model}

We use an additional step of analysis in order to understand the transition mechanism between policy and performance, as well as gain some simplicity among a fairly large set of indicators.

\subsection{A two-stage model}

This additional step takes the form of a two-stage model, which takes the following simple form:

$$
\text { Higher education policy } \rightarrow \text { Higher education performance } \rightarrow \text { Economic innovation }
$$

$$
\begin{array}{ll}
\text { Eq } 2,3,4 & \text { Eq. } 2
\end{array}
$$

Higher education policies do not affect innovation directly. Instead, they lead to performance outputs, which then may lead to greater economic innovation. We assume 
that the relationships between education policy, performance and economic innovation are linear. We limit the use of this model to a descriptive relationship between education policy and economic innovation. Three conditions would have to be fulfilled in order to establish causality: a logical chronology, a correlation between indicators and the absence of any alternative explanation. The model fulfills two of these conditions; namely a logical chronology and a correlation between indicators. Regarding the time dimension, the model introduced a two-year lag between its measure of higher education policy on the one hand and higher education performance and economic innovation on the other. The coefficients that we find reflect conditional correlations and cannot be considered to be causal relationships.

We abstain here from the extensive potential of other drivers of innovation in the university-innovation nexus. These drivers may be as varied as the existence of linkages to facilitate diffusion (such as university-innovation relationships), the overall regulatory framework, the existence of accumulated knowledge, the research and development landscape, factors specific to a particular market or product such as the level of demand and cost structure, the type of government, social infrastructures, the existence of property rights, government consumption, international openness, inflation or the ease of doing business, etc. (Hall and Jones 1999; Barro 2001; European Commission and OECD 2005:19; Goldin and Katz 2008; Archibugi et al. 2013: 124).

We also abstain from a vintage approach, well realizing that the impact of new graduates on productivity is the result of the addition to the stock of graduates.

\subsection{Non-arbitrary weights}

By comparing statistically the impact of different higher education policies on innovation we can derive non-arbitrary weights. This non-arbitrary method is particularly relevant in view of existing university rankings, e.g. Universitas21, Academic Ranking of World Universities (ARWU), Times Higher education Supplement rankings. These rankings assign weights to selected indicators based on a normative judgment of what the assessors believes is important. Webster (2001) earlier dismissed the relevance of such normative judgment, by making a thorough statistical analysis of the US News and World report rankings of colleges and universities (USNWR ranking). He used a principal component analysis to reveal some flaws in the US News \& World report rankings of colleges and universities, showing that the most significant ranking criterion should be the average SAT score of enrolled students and not (as the US News \& World report uses) academic reputation. Webster also found high multicollinearity between the indicators of the USNWR ranking. Another analysis showing how problematic the arbitrary assigning of weights can be is that by Saisana et al. (2011), who find that the inferences made by rankings for institutions and countries are not robust to changes in the weighing system.

\subsection{Factor analysis}

We conduct a factor analysis in a preliminary stage to model building. The factor analysis allows us to understand the patterns of relationships across indicators. It also allows us to group indicators to match our main categories. For example, we narrow our analysis to eight factors, which provides a more simplified approach to our data analysis process than using eighteen indicators. For example, we group relevant research indicators in a research 
performance factor (called research attractiveness and productivity), which includes five indicators.

This analysis bears additional benefits. It deals with multicollinearity, because the indicators which are highly multicollinear are grouped into a single factor. We then use OLS regressions to measure the impact of a given group of factors on another, and use the coefficients of these regressions as weights to devise a non-arbitrary weighing system.

This analysis is conducted on data standardized using a min-max technique. We use a particular variant of factor analysis which includes a non-orthogonal (oblique) rotation, called "direct oblimin" to understand patterns in the data. A rotation makes the output more understandable, by producing a pattern of loadings where items load more strongly on one factor and more weakly on others. Non-orthogonal rotation allows the factors to correlate between each other, and we allowed factors to correlate at $0.3<\gamma<0.8 ; \gamma$ standing for the correlation coefficient gamma, 0.3 for the policy and performance factors and 0.8 for the economic factors (Jenrich 1979). Relevant indicators representing university policy, performance or economic innovation are linearly combined into a number of factors.

We conduct this factor analysis on data for 32 European countries and eighteen indicators. We normalize the indicators by using a minimax technique because indicators did not all have the same measurement units ${ }^{13}$. The factor loadings are presented in Table 2.

We compute a weight for each of the policy factors, based on its statistical relation with economic output, using the variation inherent in the data for the 32 countries. These weights are based on three sets of regression coefficients.

The first OLS regression measures the impact of performance indicators for research attractiveness and productivity (Xr), international attractiveness $\mathrm{Xa}$ ), and graduation and employment, $\mathrm{Xg}$ ) on economic innovation (Xi):

$$
\mathrm{Xi} \Sigma(1,32)=\alpha \mathrm{i}+\beta 1 \mathrm{Xr}+\beta 2 \mathrm{Xa}+\beta \mathrm{Xg}+\mathrm{ei}
$$

$\Sigma(1,32)$ is used to denote the set of thirty two countries.

The other two sets of OLS regressions measure the impact of policy factors on the higher education performance:

$$
\begin{aligned}
& \operatorname{Xr} \Sigma(1,32)=\alpha r+\beta 1 \text { funding }+\beta 2 \text { policy }_{\text {autonomy }}+\beta 3 \text { managerial }_{\text {autonomy }}+\text { er } \\
& \operatorname{Xa} \Sigma(1,32)=\alpha \mathrm{a}+\beta 1 \text { funding }+\beta 2 \text { policy }_{\text {autonomy }}+\beta 3 \text { managerial }_{\text {autonomy }}+\text { ea } \\
& \operatorname{Xg} \Sigma(1,32)=\alpha \mathrm{g}+\beta 1 \text { funding }+\beta 2 \text { policy }_{\text {autonomy }}+\beta 3 \text { managerial }_{\text {autonomy }}+\text { eg }
\end{aligned}
$$

'Funding' is a factor including public funding per student as a percentage of GDP per capita and financial aid as Figure 2 shows, 'policy_autonomy' is the factor corresponding to policy autonomy and 'managerial_autonomy' is the factor corresponding to organizational and financial autonomy.

\subsection{Coefficients regarding the contribution of public funding and autonomy policies in higher education to economic innovation}

These regressions give us the coefficients presented in Table 3 for Eqs. 1, 2, 3 and 4.

Table 3 shows that research/scientific appeal, international attractiveness and graduation/ employability positively influence a country's economic innovation: increasing scientific appeal by one standard deviation corresponds to a 0.50 standard deviation increase in 
Table 2 Factors and factor loadings

\begin{tabular}{|c|c|c|c|c|c|}
\hline Dimension & Sub-dimension & Factor & Indicator & Abbreviation & Factor loading \\
\hline \multirow[t]{6}{*}{ Policy } & Funding & Funding & Public expenditure per pupil as a\% of GDP per capita & & 0.78 \\
\hline & & & $\begin{array}{l}\text { Financial aid to student as\% of total public expenditure on education, } \\
\text { at tertiary level }\end{array}$ & Fin. Aid. & 0.87 \\
\hline & & & Importance of formula and contract in the allocation of public funding & Funding allocation & $x$ \\
\hline & Autonomy & Policy autonomy & Policy autonomy & Policy autonomy & 0.84 \\
\hline & & Managerial autonomy & Organizational autonomy & Organizational autonomy & 0.83 \\
\hline & & & Financial autonomy & Financial autonomy & 0.74 \\
\hline \multirow[t]{10}{*}{ Performance } & Research & $\begin{array}{l}\text { Research attractiveness } \\
\text { and productivity }\end{array}$ & $\begin{array}{l}\text { Scientific publications within the } 10 \% \text { most cited scientific } \\
\text { publications worldwide as a } \% \text { of total scientific publications per country }\end{array}$ & Top pubs. & 0.84 \\
\hline & & & $\begin{array}{l}\text { Universities in the top } 500 \text { ARWU ranking divided by\% EU population } \\
\text { of a given country }\end{array}$ & Top 500 univers. & 0.99 \\
\hline & & & Number of incoming yearly Marie Curie fellows per million inhabitants & Marie-Curie fellows & 0.85 \\
\hline & & & $\begin{array}{l}\text { Number of yearly European Research Council starting grant wins per } \\
\text { million inhabitants }\end{array}$ & ERC wins & 0.98 \\
\hline & & & Public-private scientific co-publications per million inhabitants & Co pubs & 0.75 \\
\hline & Education & Size & Students entering higher education through an alternative route & Transition & 0.79 \\
\hline & & & Students (ISCED 5-6) aged 20 - as\% of corresponding age population & Enrolllt = enrollment; & $x$ \\
\hline & & International openness & Inward mobile students as\% of student population in the host country & Internat. students & 0.79 \\
\hline & & Graduation/graduate employment & Graduates in ISCED 5 and 6/enrollment number & Grads = graduates; & 0.85 \\
\hline & & & $\begin{array}{l}\text { Employment rates of } 18-34 \text { year olds, } 3 \text { years or less after leaving } \\
\text { formal education }\end{array}$ & Emplt = employment & 0.73 \\
\hline \multirow[t]{2}{*}{ Economic innovation } & & Economic innovation & Employment in Knowledge intensive industries as\% of total employment & Knowl. Empl. & 0.94 \\
\hline & & & GDP per hour worked in PPS euros & Labor prod. & 0.94 \\
\hline
\end{tabular}


Table 3 Regressions

\begin{tabular}{|c|c|c|c|c|c|c|}
\hline \multicolumn{7}{|c|}{ Impact of performance on economic innovation } \\
\hline & Coef. & S.E. & $\mathrm{t}$ & $P>t$ & \multicolumn{2}{|c|}{$95 \%$ confidence interval } \\
\hline Research & 0.50 & 0.14 & 3.44 & 0.00 & 0.20 & 0.80 \\
\hline Internationalization & 0.31 & 0.14 & 2.15 & 0.04 & 0.01 & 0.61 \\
\hline Grad/empl & 0.10 & 0.13 & 0.77 & 0.75 & -0.16 & 0.37 \\
\hline _cons & 0.00 & 0.13 & 0.00 & 1.00 & -0.27 & 0.27 \\
\hline \multicolumn{7}{|l|}{$\mathrm{R} 2=0.50 ; \mathrm{N}=32$} \\
\hline \multicolumn{7}{|c|}{ Impact of policy indicators on research performance } \\
\hline & Coef. & S.E. & $\mathbf{t}$ & $P>t$ & \multicolumn{2}{|c|}{$95 \%$ confidence interval } \\
\hline Funding & 0.52 & 0.14 & 3.50 & 0.00 & 0.21 & 0.83 \\
\hline Policy aut. & -0.12 & 0.15 & -0.81 & 0.42 & -0.43 & 0.18 \\
\hline Manag. Aut & 0.36 & 0.15 & 2.46 & 0.02 & 0.06 & 0.66 \\
\hline _cons & 0.00 & 0.14 & 0.00 & 1.00 & -0.29 & 0.29 \\
\hline \multicolumn{7}{|l|}{$\mathrm{R} 2=0.39 ; \mathrm{N}=32$} \\
\hline \multicolumn{7}{|c|}{ Impact of policies on internationalization } \\
\hline & Coef. & S.E. & $\mathbf{t}$ & $P>t$ & \multicolumn{2}{|c|}{$\mathbf{9 5 \%}$ confidence interval } \\
\hline Funding & 0.58 & 0.15 & 3.90 & 0.00 & 0.27 & 0.88 \\
\hline Policy aut. & 0.00 & 0.15 & -0.03 & 0.97 & -0.31 & 0.30 \\
\hline Manag. Aut & -0.26 & 0.14 & -1.76 & 0.08 & -0.56 & 0.04 \\
\hline _cons & 0.00 & 0.15 & 0.00 & 1.00 & -0.29 & 0.29 \\
\hline \multicolumn{7}{|l|}{$\mathrm{R} 2=0.39 ; \mathrm{N}=32$} \\
\hline \multicolumn{7}{|c|}{ Impact of policies on graduation and employment } \\
\hline & Coef. & S.E. & $\mathbf{t}$ & $P>t$ & \multicolumn{2}{|c|}{$\mathbf{9 5 \%}$ confidence interval } \\
\hline Funding & -0.10 & 0.18 & -0.58 & 0.56 & -0.48 & 0.26 \\
\hline Policy aut. & 0.26 & 0.18 & 1.44 & 0.16 & -0.11 & 0.64 \\
\hline Manag. Aut & -0.18 & 0.18 & -1.04 & 0.30 & -0.55 & 0.18 \\
\hline _cons & 0.00 & 0.17 & 0.00 & 1.00 & -0.36 & 0.36 \\
\hline
\end{tabular}

economic innovation, all other variables held constant. Increasing internationalization contributes to a 0.031 standard deviation increase in economic innovation. At the same time, the quality of the education system (reflected through employment/graduation) does contribute, although to a lesser extent than research, to the country's economic innovation.

The table also shows that funding and managerial autonomy relate to an increase in research performance; while policy autonomy relates to an increase in graduation and graduate employment. Policy autonomy is not significantly associated with research attractiveness and productivity. A plausible interpretation is that policy autonomy increases student graduation by providing the academic staff the ability to design their own courses and tailor them to the needs of their students in order to facilitate their learning and the acquisition of skills relevant to the labor market.

The regression results are the points of departure for the calculation of the weights to be given to the different policy elements in each of the 32 countries of Europe we have focused on.

The contribution of each policy element to economic innovation is then calculated by multiplying the regression coefficients according to the transitive and linear relationship between policy, performance and economic innovation. More precisely, we use the coefficients of the performance categories we have identified as positively affecting 
economic innovation (as research, graduation \& employment as well as internationalization). We use the significant coefficients regarding the effect of the policy dimension on these performance criteria to compute the weights because we are interested in investigating policy dynamics which can be extended beyond a hypothetical population. These weights are summarized in Table 4 below.

The largest weight is allocated to funding, followed by managerial autonomy (which is weighted as half the value of funding). Policy autonomy is nearly thirteen times smaller than funding.

These weights allow us to compare the contribution of each policy to the economic innovation of their countries. For this, we devise a score, which is computed by multiplying the size of each of the policy factors with the corresponding weights. A country score is therefore:

$$
\text { Score }=(0.26 * \text { funding })+\left(0.02 * \text { policy }_{\text {autonomy }}\right)+\left(0.10 * \text { managerial }_{\text {autonomy }}\right)
$$

\subsection{Results and interpretation}

The results are presented in Figure 3. These scores have an intuitive meaning. They are an approximation to the predicted value of economic innovativeness given our empirical model and our information on higher education policies. Roughly speaking, they tell us how innovative a country would be if higher education policies would be the only driver of economic innovativeness. The presence of negative scores in Figure 3 is due to our standardization of the policy variables. The lines in the figure represent the division according to groups of higher education assessment (top, middle and more modest). These groups are calculated based on differences in scores between countries. And the demarcation between groups is contingent on the largest difference between adjacent country values.

Note that our analysis refers to policies from 2008. Since then many changes were introduced which may have altered this overview. The research team is producing a followup version of this study, due to be published in 2014, in order to track these changes.

Norway, Cyprus, Sweden, the UK, the Netherlands and Denmark appear in the 'top group', where the higher education policies are the most supportive of its innovation systems. The UK is the only EU country with a comparatively large population in the top league (our indicators being scaled to population size).

The 'middle group' includes Germany, Belgium, Croatia, Austria, Iceland, Ireland, Italy, Finland, Slovenia, Portugal, Spain, Malta, Hungary and Estonia. A third group follows with Switzerland, France, Lithuania, Bulgaria, Poland, Turkey, Romania, Latvia, Slovakia, the Czech Republic, Luxembourg and Greece. The relatively low score for some countries, like Luxembourg, may be due to the fact that they spend less on universities than their European counterparts with a similar or lower GDP per capita. The expenditure per student as a

Table 4 Weights of policy factors on economic innovation

\begin{tabular}{lll}
\hline Weights & & \\
\hline Funding & $\left(0.52^{*} 0.50\right)$ & 0.26 \\
\hline Policy aut. & $\left(0.26^{*} 0.10\right)$ & 0.03 \\
\hline Manag. Aut & $\left(0.36^{*} 0.50\right)+\left(-0.25^{*} 0.31\right)$ & 0.10 \\
\hline
\end{tabular}




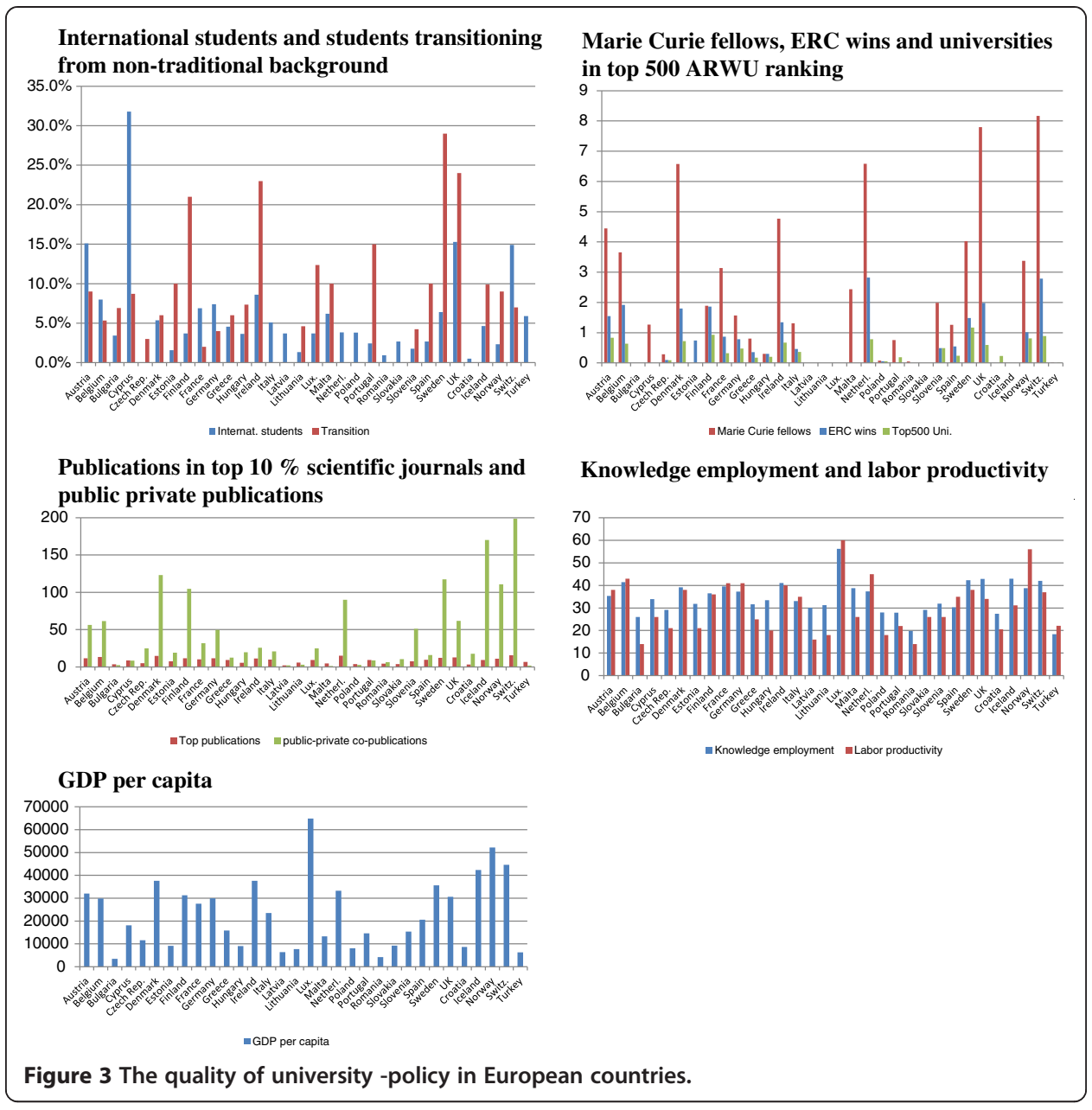

percentage of GDP per capita in Luxembourg is proportionally lower than the Czech Republic for example. This mismatch may come from the novelty and small size of its university system: the University of Luxembourg was created in 2003. Greece appears at the end of the scale. The Greek score is due to its financial commitment (Greece having among the lowest funding for higher education and financial aid according to our 2008 pre-crisis data). It also relates to government's policy on autonomy: Greece has low policy and managerial autonomy scores. Greek universities are unable to manage their assets by borrowing money, or to introduce new programs - a significant factor for educational performance according to our study.

These higher education policy assessments are only partially similar to the innovation level of countries, simply because our assessment measures the contribution of higher education policies rather than innovation per se. For example, Switzerland has comparatively high level of productivity and employment. It also has some of the highest research and graduate employment performances in Europe (with for example 91.8\% of graduates in employment three years after graduation in 2009). But this assessment is critical of Switzerland because of a comparatively low percentage of financial aid to students, which yet has to be solved by an inter-cantonal agreement. This is tantamount to saying that Switzerland could even do better in innovation, if its higher education policies were to improve. Conversely, some countries have a low level of innovation despite high public investments in higher education, as is the case for France and Germany. This 
situation may be changing. French and German reforms in autonomy and funding of 2008 may not have been transcribed in statistically visible results yet. And Germany has announced a broad investment in higher education in the form of the excellence initiative.

Infrastructures and institutions also influence higher education. And these results are only relevant in so far as we have been able to capture how policy variation create a university environment, institutions which facilitate the transmission of the knowledge created at universities in the form of human capital and research outcomes, as Aghion and Howitt (1998) indicate.

Policies which lead to highly performing universities also relate to a country's GDP per capita, as presented in Figure 4.

Figure 4 shows that highly performing countries also tend to have a higher than average GDP per capita, as is the case for Sweden, Denmark, or Norway. Conversely, countries with a lower GDP per capita have a more modest score, as is the case for Slovakia, or the Romania and Bulgaria. At the same time, less developed countries in Europe find it difficult to make quantum leaps and appear to choose for a gradual closing of the imitationinnovation gap (Aghion et al. 2009a, b). This is in deviation to the experience in South Korea in the seventies where the country pulled itself by the hairs of research policy out of the swamp of development thresholds.

Some countries, such as Cyprus, Slovenia or Croatia, however, have chosen for a progressive course (independent from their GDP per capita). Cyprus had a disproportional large public investment in higher education, Slovenia a comparatively generous financial aid schemes, and Croatia gave broad autonomy to its universities.

\section{Recommendations}

Given the contribution of higher education to economic innovation, governments should do more to integrate the promotion of economic innovation into higher education policies. Eight governments have such an integrated strategy. For example, Denmark now has a Ministry of Science, Innovation and Higher Education, the UK has established a Department for Business, Innovation and Skills while Slovenia had a Ministry of Higher Education, Science and Technology (until March 2012). Five European Governments actively encourage relevant inter-ministerial cooperation. For example in Norway the




Ministry for Trade and Industry and the one for Education and Research have established closer relations to stimulate innovation.

We also found a general positive contribution of public funding and institutional autonomy to innovation. At the same time, seventeen European Governments have reduced their public budgets for higher education, thirteen restricted financial aid programs for students, and five have restricted autonomy since 2008, all argued on the sovereign debt crises. And some Governments may feel that they are not able to make much funding leaps for higher education which are much needed to catch up in innovation. However, countries can invest in a competitive way in higher education through European funds. The use of structural and cohesion funds could improve the performance of higher education in less economically developed regions, as is the case in Poland with a multi-billion Euros investment.

The implication of the lack of translation of large investments into short-term increase in performance does not mean that the message is to reduce investment. A continuity of reforms and investments is necessary for higher education to pay off.

Finally, national Governments know how important autonomy is, but are not so sure whether universities are always able to use the autonomy with which universities are entrusted well (i.e. for societal purposes). Policy autonomy translates into relatively high levels of graduation and employment. Managerial autonomy is important for research attractiveness and research productivity, but less important for graduation and employment. Therefore, governments could engage in achieving the autonomy of universities, provided sufficient quality incentives in funding exist.

\section{Conclusions}

We address the differences in the levels of economic innovation between European countries from the perspective of higher education and higher education policies. Most highly innovative countries in Europe also make a large effort in public investment in higher education (higher education expenditures to GDP and financial aid to students). These countries also tend to provide more autonomy to their universities. In other words, we could show for 32 European countries that the degree of 'empowerment' relates to the performance of higher education and the innovative capacity of countries. This relationship mostly goes through research outputs. The throughput of higher education (graduation relative to enrolment) and graduate employment also had a positive relationship. The sheer size of the higher education student body did not positively relate to economic innovation, a result which matches a relatively long string of 'negative' results regarding the impact of education if measured only by its size (or years of education) on growth (see for example, Temple 1999 or Pritchett 2001).

Moreover, the comparison we draw between countries relies on a weighing system for policies which is theoretically and empirically based (epistemological), and superior to the a-priori fixed weights based on value judgments common in highly publicized ranking exercises.

The policy recommendations which spring from these findings are clear for those countries which want to enhance their innovation potential: focus on funding and on the institutional structure of higher education which can bring about the best results in terms of research outputs, research attractiveness and on the employability of graduates. 
The present crisis in Government budgets in many European countries should not be an excuse for lower funding and even less so for restrictions on autonomy. Higher education funding is a choice within a (limited) budget with an effect on the longer run. One might for this reason even argue that higher education expenditures could be outside the Maastricht criteria for budget deficits in EU countries. For EU countries in the catchup stage there is more over the opportunity of cohesion and structural funds to invest in higher education and research. For the EU as a whole, the Horizon 2020 program which would contribute to the higher education efforts in the EU should be enlarged, rather than curtailed in the budget negotiations for the period 2014-2017.

\section{Endnotes}

${ }^{1}$ Real GDP growth rate dropped by 4 percentage points on average between 2008 and 2009 in the euro area before increasing by 6.4 percentage points between 2009 and 2010 according to Eurostat data. These changes were not characteristic of longer term growth trends across the Euro area.

${ }^{2}$ The data for these indicators is available online at: http://empowereu.org/eeu-dataset/.

${ }^{3}$ Knowledge Intensive Activities are activities in which the percentage of tertiary education persons employed in this activity represents more than 33\% (ISCED 5-6). Knowledge Intensive Activities include for example education and telecommunications, creative arts and legal and accounting services (Eurostat 2012). The correlation coefficient between employment in KIAs and labor productivity was $r=0.79$.

4 This data includes public and private institutions. But some expenditure data for students in private institutions is not available for certain countries and some countries provide incomplete information Where this is the case, only expenditure on public and government dependent private institutions have been taken into account according to the OECD (2011: 216). We have also used World Bank data, which includes private and public institutions, with fitted values to smooth out differences for missing data.

${ }^{5}$ Eironline (2012) 'Radical changes in higher education', 20th of July, URL: http://epp. eurostat.ec.europa.eu/portal/page/portal/statistics/search_database.

${ }^{6}$ Eurostat (2008 to 2011) 'Financial aid to students as a percentage of total public expenditure on education, at tertiary level, last update 31st of July 2013 URL: http://appsso. eurostat.ec.europa.eu/nui/submitViewTableAction.do.

${ }^{7}$ One exception to this timeline concerns the publication data. We have used the most recent sources from European Commission (2011a) and European Commission (2011b), for which it seems that 2007 was the latest available data.

${ }^{8}$ Some reforms may have since affected this situation.

9 OECD (2011) Education at a glance, Paris: OECD, Table B.1.4, p. 221, column 9 (All tertiary education including R\&D activities) URL: http://www.oecd.org/education/ skills-beyond-school/48630868.pdf.

${ }^{10}$ Predicted value using World Bank 'Expenditure per student as a percentage of GDP per capita, which was $25.1 \%$ for Greece at the latest available date in 2005, URL: http://data. worldbank.org/indicator/SE.XPD.TERT.PC.ZS?page $=1$.

${ }^{11}$ The implementation of the 2008 law on the freedom and responsibilities of universities, which provided universities with more autonomy in France, was just starting at the time this data on autonomy was collected. 
12 Hence we do not include an interaction effect between policy autonomy and funding. 13 The minimax technique normalizes indicators to have the same range [0,1] by substracting the observation by the minimum value and dividing by the range of the indicator values (OECD and European Commission (2008: 28).

\section{Competing interests}

The IZA Journal of European Labor Studies is committed to the IZA Guiding Principles of Research Integrity. The authors declare that they have observed these principles.

\section{Acknowledgement}

The authors are grateful to ETS Global and RAND Europe for their support in conducting this research. Responsible editor: Martin Kahanec.

\section{Author details}

${ }^{1}$ UNU-MERITMaastricht University Keizer Karelplein 19, 6211 TC Maastricht, Netherlands. ${ }^{2}$ School of Business and Economics, Tongersestraat 53, 6211 LM Maastricht, Netherlands.

Received: 25 July 2013 Accepted: 14 November 2013

Published: 24 Dec 2013

\section{References}

Acemoglu D (2002) Technological change, inequality and the labor market. J Econ Lit 40(1):7-72

Acemoglu D, Zilibotti F, Aghion P (2006) Distance to frontier, selection and economic growth. J Eur Econ Assoc 4(1):37-74 Aghion P, Howitt P (1998) Endogenous growth theory. MIT Press, Cambridge

Aghion P, Dewatripont M, Hoxby C, Mas-Colell A, Sapir A (2007) Why reform Europe's universities. Brugel, Brussels Aghion P, Boustan L, Hoxby C, Vandenbussche J (2009a) The Causal Impact of Education on Economic Growth: Evidence from US. Harvard University, mimeo. http://scholar.harvard.edu/files/aghion/files/causal_impact_of_education.pdf

Aghion P, Dewatripont M, Hoxby C, Mas-Colell A, Sapir A (2009b) The Governance and performance of research universities: evidence from Europe and the US. National Bureau of Economic Research, Working paper 14851. http://www.nber.org/ papers/w14851

Ang J, Madsen J, Islam R (2011) The Effects of human capital composition on technological convergence. J Macroecon 33(3):465-476

Archibugi D, Filipetti A, Frenz M (2013) The impact of the economic crisis on innovation: evidence from Europe. Technol Forecast Soc Change 80:1247-1260

Asteriou D, Agiomirgianakis G (2001) Human capital and economic growth: Time series evidence from Greece. J Policy Model 23(5):481-489

Babb P, Martin J, Haezewindt P (2004) Focus on social inequalities. Office of National Statistics, London

Barro R (1991) Economic growth in a cross section of countries. Q J Econ 2:407-443

Barro RJ (2001) Human capital and growth. Am Econ Rev Pap Proc 91(2):12-17

Barro R, Lee J (1993) International comparisons of educational attainment. J Monet Econ, Elsevier 32(3):363-394

Barro J, Sala-i-Martin X1 (1995) Economic growth. McGraw-hill, Boston

Baumol W (1986) Productivity growth, convergence and welfare: what the long run data says. Am Econ Rev 76(5):1072-1085

Benhabib J, Spiegel M (2005) Human Capital and Technology Diffusion. In: Aghion P, Durlauf S (ed) Handbook of Economic Growth, 1st edition. Elsevier, London, pp 935-966. vol. 1, ch. 13

CHEPS,INCHER \& NIFU-STEPS (2008) Progress in higher education reform across Europe: governance reform. European Commission, Brussels

Eironline (2012)

Estermann T, Kanep H (2008) Financially sustainable universities: Towards full costing in European Universities. European University association, Brussels

European Commission (2011a) Innovation Union Competitiveness Report 2011 Edition. European Commission Directorate General for Research and Innovation, Brussels. http://ec.europa.eu/research/innovation-union/pdf/ competitiveness-report/2011/iuc2011-full-report.pdf\#view=fit\&pagemode=none

European Commission (2011b) Innovation Union Scoreboard 2011. http://www.proinno-europe.eu/sites/default/files/ innometrics/IUS2011.html

European Commission (2013) Progress in tackling early school leaving and raising higher education attainment - but males are increasingly left behind. Brussels. Press release, IP/13/324 11/04/2013. http://europa.eu/rapid/press-release_IP-13-324_en.htm

European Commission and OECD (2005) Oslo manual: guidelines for collecting and interpreting innovation data. OECD, Paris Eurostat (2008 to 2011) Statistics. http://epp.eurostat.ec.europa.eu/portal/page/portal/statistics/search_database

Eurostat (2012) Aggregration of Knowledge Intensive Activities based on Nace Rev. 2. http://epp.eurostat.ec.europa.eu/ cache/ITY_SDDS/Annexes/htec_esms_an8.pdf

Goldin C, Katz L (2008) The Race between Education and Technology. Harvard University Press, Cambridge

Grossman G, Helpman E (1991) Endogenous product cycles. Econ J Royal Econ Soc 101(408):1214-1229

Hall RE, Jones Cl (1999) Why do some countries produce so much more output per workers than others? Q J Econ 114 (1):83-116

Hanushek E, Woessman L (2012) Do better schools lead to more growth? Cognitive skills, economic outcomes and causation. J Econ Growth 17:267-321

Hoareau C, Ritzen J, Marconi G (2012) The State of University Policy for Progress in Europe, policy report, UNU-MERIT policy paper

Hoareau C, Ritzen J, Marconi G (2013) The state of university policy for progress in Europe. J Eur High Educ Area 1:2013

Jenrich R (1979) Admissible values of $\Upsilon$ in direct oblimin rotation. Psychometrika 44(2):173-177 
Johnstone B, Marcucci P (2010) Financing higher education worldwide: who pays? Who should pay? John Hopkins University Press, Baltimore

Kim J (1998) Economic analysis of foreign education and students abroad. J Dev Econ 56:337-365

Kimko D, Hanushek E (2000) Schooling, labor-force quality, and the growth of nations. Am Econ Rev Am Econ Assoc 90 (5):184-1208

Kneller R, Stevens P (2006) Frontier technology and absorptive capacity: evidence from OECD manufacturing industries. Oxf Bull Econ Stat 68(1):1-21

Levy F, Murnane R (2005) The New division of labor: how computers are creating the next job market? Princeton University Press, Princeton

Musselin C (2004) The Long March of French Universities. Routledge, New York

OECD (2011) Education at a Glance 2011: Main Indicators. OECD, Paris

OECD and European Commission (2008) Handbook on constructing composite indicators: methodology and user guide. OECD, Paris. http://www.oecd.org/std/42495745.pdf

Pritchett L (2001) Where has all the education gone? World Bank Econ Rev 15(3):367-391

Ritzen J (1976) Education, income inequality and economic growth. Amsterdam: North Holland

Saisana M, d'Hombres B, Saltelli A (2011) Rickety numbers: volatility of university rankings and policy implications. Research policy 40(1):165-177

Solow RM (1956) A contribution to the theory of economic growth. J Econ Growth 70(1):65-94

Swan TW (1956) Economic growth and capital accumulation. Economic Record 32(November):334-361

Temple J (1999) A positive effect of human capital on growth. Econ Lett 65(1):131-134

Van Vught F, Neave G (1991) Promotheus bound: the changing relationship between Government and higher education in Western Europe. In: Prometheus bound: the changing relationship between government and higher education in Western Europe. Pergamon Press, Michigan

Van Zon A, Antonietti R (2004) Education and training in a model of endogenous growth with creative destruction. MERIT-Infonom Res Memorand Series, 2005-011. http://arno.unimaas.nl/show.cgi?fid=1653

Vandenbussche J, Aghion P, Meghir C (2006) Growth, distance to frontier and composition of human capital. J Econ Growth 11:97-127

Volkwein J (1986) Campus Autonomy and Its Relationship of Measures of University Quality. J Higher Educ 57(5):510-528

Volkwein J, Malik S (1997) State Regulation and Administrative Flexibility at Public Universities. Res Higher Educ 38(1):17-42 Webster T (2001) A Principal component analysis of the US News and World report tier rankings of colleges and universities. Econ Educ Rev 20(3):235-244

World Bank (2013) World Bank data bank. http://data.worldbank.org/indicator/IP.PAT.RESD

10.1186/2193-9012-2-24

Cite this article as: Hoareau et al:: Higher education and economic innovation,

a comparison of European countries. IZA Journal of European Labor Studies 2013, 2:24

\section{Submit your manuscript to a SpringerOpen ${ }^{\circ}$ journal and benefit from:}

- Convenient online submission

- Rigorous peer review

- Immediate publication on acceptance

- Open access: articles freely available online

- High visibility within the field

- Retaining the copyright to your article

Submit your next manuscript at $\boldsymbol{\sim}$ springeropen.com 